\title{
ANALISIS KEMAMPUAN LITERASI SAINS \\ DI KELAS VC SD MUHAMMADIYAH CONDONGCATUR SLEMAN \\ YOGYAKARTA
}

\author{
Nunung Paryati, Fitri Yuliawati
}

PGMI FITK UIN Sunan Kalijaga

Email: fitriyulia50@gmail.com

\begin{abstract}
ABSTRAK
Penelitian ini bertujuan untuk mengetahui seberapa tinggi kemampuan literasi sains peserta didik di kelas VC SD Muhammadiyah Condongcatur Sleman Yogyakarta Tahun Ajaran 2016-2017. Penelitian ini menggunakan pendekatan kuantitatif non eksperimental dengan metode deskriptif. Teknik pengumpulan data menggunakan instrumen Tes berbentuk soal pilihan ganda yang telah divalidasi isi dan konstruk oleh ahli dan validasi empiris meggunakan program IBM SPSS Statistic 22 dengan analisis korelasi bivariat dan menggunakanrumus Product Moment Correlation. Populasinya yakni peserta didik kelas V dan sampelnya peserta didik kelas VC dengan pengambilan sampel teknik Simple Random Sampling di SD Muhammadiyah Condongcatur Sleman Yogyakarta. Analisis data yang dilakukan yakni dengan statistik deskriptif.

Dari hasil penelitian dapat disimpulkan bahwa kemampuan literasi sains peserta didik di kelas VC SD Muhammadiyah Condongcatur Sleman Yogyakarta tahun ajaran 2016-2017 terbagi menjadi 5 kriteria. Kriteria sangat tinggi terdapat 7 peserta didik atau sebanyak $19,44 \%$, kriteria tinggi terdapat 5 peserta didik atau sebanyak $13,88 \%$, kriteria sedang terdapat 16 peserta didik atau sebanyak $44,44 \%$, kriteria rendah terdapat 3 peserta didik atau sebanyak $8,33 \%$ dan kriteria sangat rendah terdapat 5 peserta didik atau sebanyak $13,88 \%$.
\end{abstract}

\section{Kata kunci: PISA, Kemampuan Literasi Sains, SD Muhammadiyah Condongcatur}

\begin{abstract}
This study aims to determine how high the ability of science literacy learners in class VC SD Muhammadiyah Condongcatur Sleman Yogyakarta Year 2016-2017. This research uses non experimental quantitative approach with descriptive method. Technique of collecting data using test instrument in the form of multiple choice that has been validated the contents and constructs by experts and empirical validation using IBM SPSS Statistic 22 program with bivariate correlation analysis and using Product Moment Correlation formula. The population is the students of class V and
\end{abstract}


the sample VC class students with sampling technique Simple Random Sampling at SD Muhammadiyah Condongcatur Sleman Yogyakarta. Data analysis is done by descriptive statistics.

The results can be concluded that the ability of science literacy learners in class VC SD Muhammadiyah Condongcatur Sleman Yogyakarta academic year 2016-2017 is divided into 5 criteria. Very high criteria there are 7 students with $19.44 \%$, high criteria there are 5 students with $13.88 \%$, medium criteria there are 16 students with $44.44 \%$, low criteria there are 3 students with $8,33 \%$ and very low criteria there are 5 students with $13.88 \%$.

\section{Keywords: PISA, Literacy Science ability, SD Muhammadiyah Condongcatur}

\section{PENDAHULUAN}

Dalam dunia pendidikan terdapat 3 kemampuan literate atau literasi yakni literasi bahasa, literasi matematika, dan literasi sains. Menurut Uus Toharudin, literasi sains sangat penting untuk dikuasai oleh peserta didik dalam kaitannya dengan cara peserta didik itu dapat memahami lingkungan hidup, kesehatan, ekonomi, dan masalah-masalah lain yang dihadapi oleh masyarakat modern yang sangat bergantung pada teknologi dan kemajuan, serta perkembangan ilmu pengetahuan. Literasi sains meliputi dua kompetensi utama. Pertama, kompetensi belajar sepanjang hayat, termasuk membekali peserta didik untuk belajar di sekolah yang lebih lanjut. Kedua, kompetensi dalam menggunakan pengetahuan yang dimilikinya untuk memenuhi kebutuhan hidupnya yang banyak dipengaruhi oleh perkembangan sains dan teknologi ${ }^{71}$.

Menurut Nasional Science Teacher Assosiation (NSTA), seseorang yang memiliki literasi sains adalah orang yang menggunakan konsep sains, mempunyai keterampilan proses sains untuk dapat menilai dalam membuat keputusan sehari-hari kalau ia berhubungan dengan orang lain, lingkungannya, serta

71 Uus Toharudin, et al., Membangun Literasi Sains Peserta Didik, (Ed) Nuryani Y. Rustaman (Bandung: Humainora, 2011), hlm. 3. memahami interaksi antara sains, teknologi, dan masyarakat, termasuk perkembangan sosial dan ekonomi. Literasi sains didefinisikan pula sebagai kapasitas untuk menggunakan pengetahuan ilmiah, mengidentifikasi pertanyaan dan menarik kesimpulan berdasarkan fakta dan data untuk memahami alam semesta dan membuat keputusan dari perubahan yang terjadi karena aktivitas manusia $^{72}$.

Hasil penilaian PISA tahun 2012 terhadap kemampuan literasi sains Indonesia adalah 375 dari nilai rata-rata 494 dan berada di peringkat 63 dari 64 anggota. Hasil ini menunjukkan bahwa kemampuan berliterasi manusia Indonesia masih rendah. Di lingkup Asia Tenggara (ASEAN) posisi Indonesia masih di belakang Vietnam (411), Thailand (427), dan Malaysia (421) ${ }^{73}$. Kondisi tidak

72 Asri Sutisnawati, "Membangun Imajinasi dan Kreativitas Anak Melalui Literasi Sains" (Penerapan Literasi Sains di Sekolah Dasar), vol 2, Prosiding Seminar Pendidikan Dasar, UPI, 2015.

akses di http:// eprints.uad.ac.id $/ 2845 / 1 / \% 5 B B U R N \% 5 \mathrm{D} \% 20$ Prosiding\%20Pendas\%202015\%20Vol\%20 2. pdf pada tanggal 17 April 2017 pukul 12.00 WIB.

73 Bahrul Hayat dan Suhendra Yusuf, Benchmark Internasional Mutu Pendidikan, (Jakarta: Bumi Aksara, 2010), hlm. 10-12. 
berbeda juga dihadapi oleh pelajar di kota melibatkan isu-isu yang sangat penting dalam Yogyakarta yang menyandang predikat kota kehidupan secara umum, seperti juga terhadap pendidikan. Hal ini dapat dilihat dari hasil INAP kepedulian pribadi ${ }^{75}$.

(Indonesia National Assesment Programme) 2012 yang diselenggarakan oleh Pusat Penelitian Pendidikan (Puspendik) Badan Penelitian dan Pengembangan (Balitbang) Kementrian Pendidikan dan Kebudayaan Republik Indonesia dengan melibatkan 2 Provinsi perintis, yaitu DIY dan Kalimantan Timur. Berdasarkan skor yang didapat, terlihat bahwa tingkat literasi sains peserta didik DIY hanya menunjukkan hasil yang baik pada level knowing, namun kurang baik di level applying, bahkan lebih kurang lagi di level reasoning ${ }^{74}$.

Dalam pengukuran literasi sains, PISA menetapkan tiga dimensi besar literasi sains, yakni konten sains, proses sains, dan konteks aplikasi sains. Secara rinci, PISA, pada 2003, memaparkan dimensiliterasi sains sebagai berikut. Pertama, kandungan (konten) literasi sains yang berarti dalam dimensi konsep ilmiah peserta didik perlu menangkap sejumlah konsep kunci atau esensial untuk dapat memahami fenomena alam tertentu dan perubahan-perubahan yang terjadi akibat kegiatan manusia. Kedua, proses literasi sains dalam PISA mengkaji kemampuan peserta didik untuk menggunakan pengetahuan dan pemahaman ilmiah, seperti kemampuan peserta didik untuk mencari, menafsirkan dan memperlakukan bukti-bukti. PISA menguji lima proses semacam itu, yakni mengenali pertanyaan ilmiah (i), mengidentifikasi bukti (ii), menarik kesimpulan (iii), mengomunikasikan kesimpulan (iv), dan menunjukkan pemahaman konsep ilmiah (v). Yang ketiga yakni konteks (sikap) literasi sains dimana seseorang yang mampu

74 Anonim (Artikel), Taman Pintar Science Center sebagai Sarana Litersi Sains Masyarakat, di akses di http:/inovasi.lan.go.id/index. php? $\mathrm{f}=$ download/getFile\&id $=293$ pada tanggal 16 Maret 2017 pukul 17.15 WIB.
Pada PISA 2006 ruang lingkup literasi sains dijelaskan dalam tabel di bawah ini ${ }^{76}$ (hlm. 61).

Literasi sains dapat dikembangkan melalui wacana (bacaan) dalam buku teks atau buku pelajaran sains. Terdapat dua hal yang perlu diperhatikan dalam menilai tingkat literasi sains peserta didik, yaitu ${ }^{77}$ :

a. Penilaian literasi sains peserta didik tidak ditujukan untuk membedakan seorang literat atau tidak.

b. Pencapaian literasi sains merupakan proses yang kontinu dan terus menerus berkembang sepanjang hidup manusia.

Untuk mengetahui kemampuan literasi sains ini maka perlu diadakan pengukuran. Pengukuran yang peneliti lakukan dengan menggunakan instrumen tes, dan tes yang digunakan yakni tes tertulis berupa soal pilihan ganda. Soal-soal Literasi Sains dalam PISA memiliki beberapa karakteristik tertentu, yaitu: a. Soal-soal yang mengandung konsep tidak langsung terkait dengan konsep-konsep dalam kurikulum manapun, tetapi lebih diperluas.

b. Soal-soal literasi sains dalam PISA menyediakan sejumlah informasi atau data dalam berbagai bentuk penyajian untuk diolah oleh peserta didik yang akan menjawabnya.

c. Soal-soal literasi sains dalam PISA me-

75 Uus Toharudin, et al..Membangun Literasi Sains Peserta Didik...,hlm.8-9.

76 Asri Sutisnawati, Membangun Imajinasi dan Kreativitas, prosiding.., hlm.68-69.

77 Asri Sutisnawati, "Membangun Imajinasi dan Kreativitas", Prosiding..., hal. 70-71. 
Tabel.1 Domain/Dimensi Literasi Sains PISA 2006

\begin{tabular}{|c|c|}
\hline Ruang Lingkup & Indikator \\
\hline $\begin{array}{l}\text { Pengetahuan Ilmiah dan } \\
\text { Konten }\end{array}$ & $\begin{array}{l}\text { Mmerujuk pada pengetahuan sains dan pengetahuan tentang sains } \\
\text { serta situasi hidup yang melibatkan sains dan teknologi. }\end{array}$ \\
\hline \multirow[t]{3}{*}{$\begin{array}{l}\text { Proses Sains dan } \\
\text { Kompetensi }\end{array}$} & $\begin{array}{l}\text { 1) Menggunakan bukti ilmiah, yaitu kemampuan menafsirkan bukti } \\
\text { ilmiah dan menarik kesimpulan, mengindentifikasi asumsi, bukti } \\
\text { dan alasan berdasarkan kesimpulan dan membuat refleksi implikasi } \\
\text { sosial dari perkembangan sains dan teknologi }\end{array}$ \\
\hline & $\begin{array}{l}\text { 2) Menjelaskan fenomena ilmiah, yaitu kemampuan untuk } \\
\text { mengaplikasikan pengetahuan sains dalam situasi yang diberikan, } \\
\text { mendeskripsikan/menafsirkan fenomena ilmiah dan memprediksi } \\
\text { perubahannya, dan mengindetifikasi, deskripsi, eksplanasi dan } \\
\text { prediksi yang sesuai. }\end{array}$ \\
\hline & $\begin{array}{l}\text { 3) Mengidentifikasi isu-isu ilmiah, yaitu kemampuan untuk } \\
\text { mengenal isu-isu yang mungkin diselidiki secara ilmiah, } \\
\text { mengidentifikasi kata-kata kunci untuk memperoleh informasi } \\
\text { ilmiah dan mengenal fitur-fitur (ciri khas) penyelidikan ilmiah. }\end{array}$ \\
\hline \multirow[t]{3}{*}{ Sikap Sains } & $\begin{array}{l}\text { 1) Mendukung inquiry sains, yaitu kemampuan untuk menyatakan } \\
\text { pentingnya mempertimbangkan perbedaan perspektif sains dan } \\
\text { argumen, mendukung penggunaan informasi faktual dan eksplanasi, } \\
\text { dan menunjukkan kebutuhan untuk proses logis dan ketelitian } \\
\text { dalam menarik kesimpulan. }\end{array}$ \\
\hline & $\begin{array}{l}\text { 2) Ketertarikan terhadap sains, yaitu kemampuan untuk } \\
\text { menunjukkan rasa ingin tahu dalam ilmu pengetahuan dan ilmu } \\
\text { yamg berhubungan dengan isu-isu, menunjukkan keinginan untuk } \\
\text { memperoleh pengetahuan ilmiah dan keterampilan tambahan, } \\
\text { dengan menggunakan berbagai sumber belajar dan metode, dan } \\
\text { menunjukkan kemauan untuk mencari informasi dan memiliki } \\
\text { kepentingan yang sedang berlangsung dalam ilmu pengetahuan, } \\
\text { termasuk pertimbangan ilmu pengetahuan yang berhubungan } \\
\text { dengan karier. }\end{array}$ \\
\hline & $\begin{array}{l}\text { 3) Bertanggung jawab terhadap sumber dan lingkungan alam, } \\
\text { yaitu kemampuan untuk menunjukkan rasa tanggung jawab secara } \\
\text { personal untuk memelihara lingkungan, menunjukkan kepedulian } \\
\text { pada dampak lingkungan akibat perilaku manusia dan menunjukkan } \\
\text { kemauan untuk mengambil sikap menjaga sumber alam. }\end{array}$ \\
\hline
\end{tabular}


minta peserta didik mengolah (menghubung-hubungkan) informasi dalam soal.

d. Pernyataan yang menyertai pertanyaan dalam soal perlu dianalisis dan diberi alasan saat menjawabnya.

e. Soal-soal tersebut disajikan dalam bentuk bervariasi, bentuk pilihan ganda, isian singkat atau esai.

f. Soal PISA mencakup konten aplikasi (personal-komunitas- global, kehidupan-kesehatan-bumi dan lingkungan- teknologi) yang kaya.

\section{METODE PENELITIAN}

Penelitian ini merupakan penelitian dengan pendekatan kuantitatif noneksperimental. Pada penelitian ini peneliti menggunakan metode deskriptif. Metode deskriptif (descriptive research) adalah suatu metode penelitian yang ditunjukkan untuk menggambarkan fenomena-fenomena yang ada, yang berlangsung pada saat ini atau saat yang lampau. Penelitian ini tidak mengadakan manipulasi atau pengubahan pada variabel-variabel bebas, tetapi menggambarkan suatu kondisi apa adanya. Lokasi yang dijadikan tempat penelitian yakni SD Muhammadiyah Condongcatur Sleman Yogyakarta yang beralamat di J1 Perumas, Ring Road Utara, Gorongan, Condongcatur, Depok, Sleman DIY. Waktu penelitian yakni pada bulan April 2017.

Populasi penelitian dalam penelitian ini adalah peserta didik kelas $\mathrm{V}$ di SD Muhammadiyah Condongcatur tahun ajaran 2016/2017. Sampel penelitian ini adalah kelas $\mathrm{VC}$ dengan jumlah 36 peserta didik. Instrumen penelitian menggunakan dua tipe soal, yaitu soal objektif dan soal uraian yang telah di validasi isi dan konstruk.

Teknik analisis data yang digunakan dalam penelitian ini adalah statistik deskriptif. Untuk mengetahui kemampuan literasi sains peserta didik dengan cara menganalisis data jawaban soal yang telah diberikan dengan memberikan skor dengan bantuan Microsoft Excel dengan sebagian besar menggunakan rumus SUM atau rumus yang digunakan untuk mencari total dan menggunakan kunci jawaban pada tes yang telah dibuat oleh peneliti. Jawaban benar akan mendapat skor 1, jika salah atau tidak menjawab diberi skor 0 . Untuk menghitung nilai kemampuan literasi sains setiap dimensi literasi sains dan masing-masing sampel dilakukan sebagai berikut:

\begin{tabular}{|c|l|}
\hline \multicolumn{2}{|c|}{ Skor akhir $=\mathbf{R} / \mathbf{N} \times 100$} \\
\hline $\mathbf{S}$ & $\begin{array}{l}\text { Skor akhir kemampuan literasi } \\
\text { sains }\end{array}$ \\
\hline $\mathbf{R}$ & Skor jawaban yang benar \\
\hline $\mathbf{N}$ & Jumlah skor maksimum dari tes \\
\hline
\end{tabular}

\section{HASILPENELITIANDAN PEMBAHASAN}

Hasil penelitian berisi pengolahan jawaban peserta didik yang diperoleh dari hasil mengerjakan tes yang peneliti berikan. Hasil tersebut telah divalidasi empiris dengan analisis Korelasi bivariat (analisys correlate bivariate) dan menggunakan program IBM SPSS Statistic 22.

Dalam pengolahan dengan menggunakan SPSS dilakukan validasi butir soal (Analisis Butir) dengan menggunakan rumus Product Moment Correlation yang ada pada korelasi bivariat. Dalam hal ini skor tiap butir soal 
untuk tiap responden dikorelasikan dengan skor tiap total responden yang bersangkutan. Hasil yang didapat, dibandingkan degan nilai r (nilai korelasi) pada tabel Product Moment Correlation.3.

Nilai r (nilai korelasi) pada tabel Product Moment Correlation untuk sampel/responden 36 yakni taraf signifikan $5 \%$ adalah 0,329 dan taraf signifikan $1 \%$ adalah 0,430 . Sesuai dengan rumusnya maka $\mathrm{r}(0,05, \mathrm{n}-2)$ yang digunakan adalah jumlah $\mathrm{N}$ (sampel/responden) 34 dengan nilai untuk taraf signifikan 5\% 0,339 dan taraf signifikan $1 \%$ adalah $0,436 \% .4$

Hasil analisis butir soal dengan menggunakan program SPSS IBM SPSS Statistic 22 dengan rumus Product Moment Correlation yakni dari 30 butir soal didapatkan 13 soal valid. Yakni butir soal/ soal nomor 1 dengan $r$ 0,489, nomor 2 dengan $r$ 0,763, nomor 4 dengan $\mathrm{r}$ 0,439, nomor 5 dengan $\mathrm{r}$ 0,439 nomor 10 dengan $\mathrm{r} 0,737$, nomor 11 dengan r 0,438 , nomor 12 dengan r 0,510 , nomor 13 dengan r 0,347, nomor 14 dengan $r$ 0,547, nomor 20 dengan $r 0,351$, nomor 25 dengan $r$ 0,342 , nomor 26 dengan $\mathrm{r} 0,424$ dan nomor 30 dengan $r 0,427$.

Terdapat tiga tabel yang menunjukkan hasil tersebut, satu tabel pertama menunjukkan data pada pengukuran literasi sains dimensi konten. Indikator pada dimensi konten yakni merujuk pada pengetahuan sains dan pengetahuan tentang sains serta situasi hidup yang melibatkan sains dan teknologi. Ini berarti melihat bagaimana peserta didik menguasai teori sains yang sudah dipelajarinya. Hasil penelitian tersebut dapat dilihat pada tabel di bawah ini (hlm. 65).
Pengukuran pertama dimensi konten sains, dengan indikator yakni merujuk pada pengetahuan sains dan pengetahuan tentang sains serta situasi hidup yang melibatkan sains dan teknologi. Ini dimaksudkan bagaimana pengetahuan atas teori-teori sains yang dimiliki peserta didik. Di bawah ini akan peneliti jelaskan bagaimana kemampuan literasi sains yang sudah diukur berdasarkan soal yang sudah diberikan.

Pada soal nomor 1 tentang teori penguapan, disajikan sebuah soal berisi gambar dan paragraf cerita seorang peserta didik bernama Iman, percobaan tersebut mengenai penguapan pada es batu yang dipanaskan. Iman menyimpan potongan es batu di sebuah wadah yang sudah dilapisi oleh kain kasa dan diberi spirtus yang sudah dinyalakan di bawahnya.

Peserta didik diminta memberikan dugaan terkuat terhadap hasil percobaan tentang penguapan tersebut. Pilihan jawabannya yakni pertama (a) besar kecilnya gelas kimia mempengaruhi waktu proses penguapan, kedua (b) yakni tebal tipisnya kain kasa mempengaruhi waktu proses pengupan. Ketiga (c), proses penguapan dipengaruhi oleh kondisi spirtus yang harus tetap menyala dan keempat yakni proses penguapan dipengaruhi oleh banyaknya es batu yang ada dalam gelas kimia.

Jawaban yang paling tepat dari empat pilihan di atas yakni pilihan ketiga (c) atau proses penguapan dipengaruhi oleh kondisi spirtus yang harus tetap menyala. Berdasarkan hasil pengukuran literasi sains dimensi konten didapat jumlah peserta didik yang dapat menjawab benar yakni sebanyak 55, 56\%.

Soal nomor 2 tentang faktor penyebab terjadinya penguapan, soal masih terkait dengan percobaan yang dipertanyakan di soal nomor 1 . Pertanyaan yakni faktor apakah yang 
Analisis Kemampuan Literasi Sains di Kelas VC SD Muhammadiyah Condongcatur Sleman YK

Tabel 2.Hasil Penelitian Literasi Sains Dimensi Konten

\begin{tabular}{|c|c|c|c|c|c|c|c|c|}
\hline \multirow[t]{2}{*}{ Sampel } & \multicolumn{4}{|c|}{ No } & \multirow[t]{2}{*}{$\mathbf{R}$} & \multirow[t]{2}{*}{$\mathbf{N}$} & \multirow[t]{2}{*}{ Skor } & \multirow[t]{2}{*}{ Kriteria } \\
\hline & 1 & 2 & 10 & 11 & & & & \\
\hline 1 & 0 & 0 & 0 & 1 & 1 & 4 & 25 & Sangat Rendah \\
\hline 2 & 0 & 1 & 1 & 1 & 3 & 4 & 75 & Sedang \\
\hline 3 & 0 & 1 & 1 & 1 & 3 & 4 & 75 & Sedang \\
\hline 4 & 0 & 0 & 1 & 1 & 2 & 4 & 50 & Sangat Rendah \\
\hline 5 & 1 & 0 & 0 & 1 & 2 & 4 & 50 & Sangat Rendah \\
\hline 6 & 1 & 0 & 0 & 1 & 2 & 4 & 50 & Sangat Rendah \\
\hline 7 & 0 & 0 & 0 & 1 & 1 & 4 & 25 & Sangat Rendah \\
\hline 8 & 1 & 1 & 1 & 1 & 4 & 4 & 100 & Sangat Tinggi \\
\hline 9 & 0 & 0 & 1 & 1 & 2 & 4 & 50 & Sangat Rendah \\
\hline 10 & 0 & 1 & 1 & 1 & 3 & 4 & 75 & Sedang \\
\hline 11 & 1 & 1 & 1 & 1 & 4 & 4 & 100 & Sangat Tinggi \\
\hline 12 & 1 & 1 & 1 & 1 & 4 & 4 & 100 & Sangat Tinggi \\
\hline 13 & 0 & 0 & 1 & 1 & 2 & 4 & 50 & Sangat Rendah \\
\hline 14 & 1 & 0 & 0 & 1 & 2 & 4 & 50 & Sangat Rendah \\
\hline 15 & 1 & 1 & 0 & 1 & 3 & 4 & 75 & Sedang \\
\hline 16 & 0 & 1 & 1 & 1 & 3 & 4 & 75 & Sedang \\
\hline 17 & 1 & 1 & 1 & 1 & 4 & 4 & 100 & Sangat Tinggi \\
\hline 18 & 0 & 0 & 0 & 1 & 1 & 4 & 25 & Sangat Rendah \\
\hline 19 & 0 & 0 & 0 & 0 & 0 & 4 & 0 & Sangat Rendah \\
\hline 20 & 1 & 0 & 1 & 1 & 3 & 4 & 75 & Sedang \\
\hline 21 & 1 & 0 & 1 & 1 & 3 & 4 & 75 & Sedang \\
\hline 22 & 1 & 1 & 1 & 1 & 4 & 4 & 100 & Sangat Tinggi \\
\hline 23 & 0 & 0 & 0 & 1 & 1 & 4 & 25 & Sangat Rendah \\
\hline 24 & 1 & 0 & 0 & 1 & 2 & 4 & 50 & Sangat Rendah \\
\hline 25 & 1 & 1 & 1 & 1 & 4 & 4 & 100 & Sangat Tinggi \\
\hline 26 & 0 & 1 & 1 & 1 & 3 & 4 & 75 & Sedang \\
\hline 27 & 1 & 0 & 0 & 1 & 2 & 4 & 50 & Sangat Rendah \\
\hline 28 & 0 & 1 & 0 & 1 & 2 & 4 & 50 & Sangat Rendah \\
\hline 29 & 1 & 1 & 1 & 1 & 4 & 4 & 100 & Sangat Tinggi \\
\hline 30 & 0 & 0 & 0 & 1 & 1 & 4 & 25 & Sangat Rendah \\
\hline 31 & 1 & 0 & 0 & 0 & 1 & 4 & 25 & Sangat Rendah \\
\hline 32 & 1 & 1 & 1 & 1 & 4 & 4 & 100 & Sangat Tinggi \\
\hline 33 & 1 & 1 & 0 & 1 & 3 & 4 & 75 & Sedang \\
\hline 34 & 0 & 1 & 0 & 1 & 2 & 4 & 50 & Sangat Rendah \\
\hline 35 & 1 & 0 & 0 & 1 & 2 & 4 & 50 & Sangat Rendah \\
\hline 36 & 1 & 0 & 0 & 1 & 2 & 4 & 50 & Sangat Rendah \\
\hline Total benar & 20 & 17 & 18 & 34 & & & & \\
\hline Persentase & $55,56 \%$ & $47,22 \%$ & $50,00 \%$ & $94,44 \%$ & & & & \\
\hline
\end{tabular}


menyebabkan terjadinya proses penguapan. Dengan pilihan jawaban adanya potongan es batu, adanya spirtus yang menyala, adanya kain kassa, adanya suhu ruangan. Jawaban yang benar dari pertanyaan nomor 2 yakni adanya spirtus yang menyala. Jumlah peserta didik yang dapat menjawab benar yakni sebanyak 47, 22\%. Peserta didik yang menjawab benar kurang dari $50 \%$, ini bisa disebabkan penguasaan materi yang kurang.

Soal nomor 10 tentang proses hujan, dengan soal sebagai berikut: air hujan yang turun sebagai hujan, ternyata sebagian besar berasal dari penguapan air laut yang asin. Tetapi ketika air hujan meresap ke dalam tanah dan mengalir ke permukaan tanah memiliki sifat yang tawar. Apa yang menyebabkan hal tersebut terjadi. Pilihan jawaban yang disediakan yakni pertama (a) karena air laut berasal dari air sungai yang memiliki sifat tawar, kedua (b) karena air laut yang menguap akan berubah menjadi air tawar, ketiga (c) karena garam tidak ikut mengembun dan tidak turun sebagai hujan dan terakhir (d) karena garam tidak ikut menguap pada terjadinya penguapan air laut.

Pilihan jawaban yang benar yakni pilihan keempat (d) yang menyatakan bahwa air hujan tidak berasa asin padahal berasal dari air laut karena garam tidak ikut menguap pada terjadinya siklus hujan pada penguapan air laut. Jumlah peserta didik yang dapat menjawab benar sebanyak $50 \%$, jika ada 36 peserta didik yang menjadi sampel berarti hanya 18 orang yang menjawab dengan tepat.

Soal nomor 11 tentang peristiwa evaporasi atau peristiwa penguapan. disajikan empat pilihan jawaban pernyataan yakni pertama (a) es batu yajng dibuat dalam kantung plastik akan mengembung karena pertambahan volume.
Kedua (b) air yang direbus akan mendidih pada suhu $100^{\circ} \mathrm{C}$ dan air akan menjadi uap yang keluar dari panci. Ketiga (c) mentega yang didinginkan di dalam lemari es lama kelamaan akan membeku. Keempat (d) es krim yang dikeluarkan dari freezer lama kelamaan akan mencair. Dari empat pilihan tersebut peserta didik diminta memilih jawaban yang benar tentang contoh yang merupakan proses evaporasi.

Jawaban yang benar yakni pernyataan atau pilihan jawaban kedua (b). Didapat jumlah peserta didik yang dapat menjawab benar yakni sebanyak $94,44 \%$. Nilai persentase yang tinggi tersebut menandakan peserta didik menguasai mengenai materi tersebut, bisa juga karena pengalaman peserta didik ketika melihat penguapan air yang direbus dalam panci yang sering diketemui pada kehidupan sehari-hari.

Tabel kedua menunjukkan hasil pengukuran literasi sains pada dimensi proses. Terdapat dua indikator pada dimensi proses yakni Indikator proses menggunakan bukti Ilmiah berupa kemampuan untuk menafsirkan bukti ilmiah dan menarik kesimpulan, mengidentifikasi asumsi, bukti dan alasan berdasarkan kesimpulan, dan membuat refleksi implikasi sosial dari perkembangan sains dan teknologi.

Indikator kedua yakni indikator proses menjelaskan bukti ilmiah yakni kemampuan untuk mengaplikasikan pengetahuan sains dalam situasi yang diberikan, mendeskripsikan/ menafsirkan fenomena ilmiah dan memprediksi perubahannya, dan mengidentifikasi, deskripsi, eksplanasi dan prediksi yang sesuai. Hasil penelitian pada kedua indikator tersebut dapat dilihat pada tabel di bawah ini. 
Analisis Kemampuan Literasi Sains di Kelas VC SD Muhammadiyah Condongcatur Sleman YK

Tabel 3.Hasil Penelitian Literasi Sains Dimensi Proses Indikator Menggunakan Bukti Ilmiah dan Menjelaskan Fenomena Ilmiah

\begin{tabular}{|c|c|c|c|c|c|c|c|c|}
\hline \multirow[b]{2}{*}{ Sampel } & \multicolumn{4}{|c|}{ No soal } & \multirow[b]{2}{*}{$\mathbf{R}$} & \multirow[b]{2}{*}{$\mathbf{N}$} & \multirow[b]{2}{*}{ Skor } & \multirow[b]{2}{*}{ Kriteria } \\
\hline & 4 & 5 & 12 & 25 & & & & \\
\hline 1 & 1 & 0 & 1 & 1 & 3 & 4 & 75 & Sedang \\
\hline 2 & 1 & 1 & 0 & 0 & 2 & 4 & 50 & Sangat Rendah \\
\hline 3 & 1 & 1 & 1 & 1 & 4 & 4 & 100 & Sangat Tinggi \\
\hline 4 & 1 & 1 & 1 & 1 & 4 & 4 & 100 & Sangat Tinggi \\
\hline 5 & 1 & 0 & 1 & 1 & 3 & 4 & 75 & Sedang \\
\hline 6 & 1 & 1 & 1 & 1 & 4 & 4 & 100 & Sangat Tinggi \\
\hline 7 & 0 & 1 & 0 & 0 & 1 & 4 & 25 & Sangat Rendah \\
\hline 8 & 1 & 1 & 1 & 1 & 4 & 4 & 100 & Sangat Tinggi \\
\hline 9 & 1 & 1 & 0 & 1 & 3 & 4 & 75 & Sedang \\
\hline 10 & 0 & 1 & 1 & 1 & 3 & 4 & 75 & Sedang \\
\hline 11 & 1 & 1 & 1 & 1 & 4 & 4 & 100 & Sangat Tinggi \\
\hline 12 & 1 & 1 & 1 & 1 & 4 & 4 & 100 & Sangat Tinggi \\
\hline 13 & 1 & 1 & 1 & 0 & 3 & 4 & 75 & Sedang \\
\hline 14 & 1 & 1 & 0 & 1 & 3 & 4 & 75 & Sedang \\
\hline 15 & 1 & 1 & 0 & 1 & 3 & 4 & 75 & Sedang \\
\hline 16 & 1 & 1 & 1 & 0 & 3 & 4 & 75 & Sedang \\
\hline 17 & 1 & 0 & 1 & 1 & 3 & 4 & 75 & Sedang \\
\hline 18 & 1 & 1 & 0 & 1 & 3 & 4 & 75 & Sedang \\
\hline 19 & 1 & 0 & 0 & 0 & 1 & 4 & 25 & Sangat Rendah \\
\hline 20 & 1 & 1 & 1 & 1 & 4 & 4 & 100 & Sangat Tinggi \\
\hline 21 & 1 & 1 & 1 & 1 & 4 & 4 & 100 & Sangat Tinggi \\
\hline 22 & 1 & 0 & 1 & 1 & 3 & 4 & 75 & Sedang \\
\hline 23 & 0 & 1 & 0 & 1 & 2 & 4 & 50 & Sangat Rendah \\
\hline 24 & 0 & 1 & 0 & 0 & 1 & 4 & 25 & Sangat Rendah \\
\hline 25 & 1 & 1 & 1 & 1 & 4 & 4 & 100 & Sangat Tinggi \\
\hline 26 & 1 & 1 & 0 & 0 & 2 & 4 & 50 & Sangat Rendah \\
\hline 27 & 1 & 1 & 0 & 1 & 3 & 4 & 75 & Sedang \\
\hline 28 & 1 & 1 & 1 & 0 & 3 & 4 & 75 & Sedang \\
\hline 29 & 1 & 1 & 1 & 1 & 4 & 4 & 100 & Sangat Tinggi \\
\hline 30 & 0 & 0 & 0 & 1 & 1 & 4 & 25 & Sangat Rendah \\
\hline 31 & 1 & 0 & 1 & 0 & 2 & 4 & 50 & Sangat Rendah \\
\hline 32 & 0 & 1 & 1 & 1 & 3 & 4 & 75 & Sedang \\
\hline 33 & 1 & 1 & 0 & 0 & 2 & 4 & 50 & Sangat Rendah \\
\hline 34 & 0 & 1 & 1 & 0 & 2 & 4 & 50 & Sangat Rendah \\
\hline 35 & 1 & 1 & 1 & 1 & 4 & 4 & 100 & Sangat Tinggi \\
\hline 36 & 0 & 0 & 0 & 1 & 1 & 4 & 25 & Sangat Rendah \\
\hline Total Benar & 28 & 28 & 22 & 25 & & & & \\
\hline Persentase & $77,77 \%$ & $77,77 \%$ & $61,11 \%$ & $69,44 \%$ & & & & \\
\hline
\end{tabular}


Soal nomor 4 mengenai materi penguapan. Peserta didik diberikan pertanyaan mengenai cara mempercepat proses penguapan. Pilihan jawaban yang diberikan yakni memperkecil bidang penguapan, memperbesar kristal larutan, menaikkan suhu atau memanaskannya dan terakhir menambah tekanan di atas permukaan. Pilihan jawaban yang benar yakni pilihan jawaban ketiga (c) yakni menaikkan suhu atau memanaskannya, dengan suhu yang lebih tinggi proses penguapan juga semakin cepat. Jumlah peserta didik yang dapat menjawab benar yakni sebanyak $77,77 \%$.

Soal nomor 5 tentang proses perubahan wujud benda, peserta didik diminta memilih jawaban yang berbentuk pertanyaan yang jawabannya terdapat pada paragraf tentang pembekuan air di freezer. Paragraf tersebut menceritakan bahwa seorang anak bernama Icha menyimpan air di dalam freezer, setelah beberapa jam air yang disimpan oleh Icha membeku dan berubah menjadi es batu. Setelah es batu dikeluarkan dari freezer dan dibiarkan pada ruang terbuka, es berubah menjadi air lagi.

Berdasarkan paragraf yang tertera pada soal nomor 5 , peserta didik diminta menduga mengenai pertanyaan apa yang bisa dijawab berdasarkan paragraf tersebut. Pilihan jawabannya yakni pertama (a) bagaimana pengaruh suhu terhadap perubahan wujud air, kedua (b) bagaimana pengaruh jumlah air terhadap terhadap perubahan wujud air, ketiga (c) bagaimana pengaruh bentuk wadah air terhadap perubahan wujud air, dan terakhir bagaimana pengaruh ukuran freezer terhadap perubahan wujud air. Pilihan jawaban yang benar yakni pilihan pertama (a), bagaimana pengaruh suhu terhadap perubahan wujud air. Jumlah peserta didik yang dapat menjawab benar yakni 77, 77\%.
Soal nomor 12 tentang tumbuhan, peserta didik diminta memilih jawaban yang benar tentang percobaan seperti apakah yang dapat membuktikan bahwa tumbuhan dapat membantu penyerapan air. Pilihan jawaban yang disediakan yakni pertama (a) buatlah dua wadah, wadah pertama hanya berisi tanah dan dan wadah kedua berisi tanah yang ditanami rumput. Kemudian disiram dengan air yang sama banyaknya untuk melihat aliran air yang keluar. Kedua (b) sediakan dua pot tanaman, kemudian masing-masing tanaman disiram dengan air dan air asam, lakukan beberapa kali dan lihat hasilnya. Ketiga (c) isilah pot dengan pasir lalu tambahkan batu-batu krikil, letakkan pot bunga diatas toples yang masih kosong kemudian air yang kotor dituangkan ke dalam pot bunga. Lihat air hasil tampungan. Pilihan jawaban terakhir (d) yakni isi gelas dengan air berwarna, kemudian masukkan tisu dalam posisi tegak, biarkan beberapa saat dan amati apa yang terjadi.

Berdasarkan empat pilihan jawaban d iatas, percobaan yang bisa membuktikan bahwa tumbuhan dapat membantu penyerapan air adalah pilihan jawaban pertama (a). Dari jawaban tersebut kita ketahui bahwa tumbuhan membutuhkan air dilihat dari jumlah air yang keluar lebih sedikit pada wadah yang terdapat tanamannya. Ini menandakan bahwa tanaman tersebut meyerap air yang telah disiramkan, sedangkan pada wadah yang kosong jumlah/ volume air tetap akan banyak/tidak berkurang secara signifikan. Untuk soal no.12 Jumlah peserta didik yang dapat menjawab benar yakni sebanyak $61,11 \%$.

Soal nomor 25 tentang keanekaragaman ekosistem biotik yang ada di Indonesia, peserta didik diminta memilih jawaban 
yang benar tentang alasan mengapa Indonesia memiliki keanekaragaman biotik. Empat pilihan jawabannya yakni karena keragaman flora dan fauna, Indonesia sebagai negara kepulauan, SDA yang melimpah dan banyaknya hewan dan tumbuhan langka. Jawaban yang benar yakni dikarenakan keragaman flora dan fauna maka Indonesia memiliki keanekaragaman biotik. Jumlah peserta didik yang dapat menjawab benar yakni sebanyak 69, 44\%.

Tabel ketiga menunjukkan data dari hasil penelitian yakni pengukuran literasi sains pada dimensi sikap sains. Terdapat dua indikator yakni indikator sikap Ketertarikan terhadap sains yakni kemampuan untuk menunjukkan rasa ingin tahu dalam ilmu pengetahuan dan ilmu yang berhubungan dengan isu-isu, menunjukkan keinginan untuk memperoleh pengetahuan ilmiah dan keterampilan tambahan, dengan menggunakan berbagai sumber belajar dan metode, menunjukkan kemauan untuk mencari informasi dan memiliki kepentingan yang sedang berlangsung dalam ilmu pengetahuan,termasuk pertimbangan ilmu pengetahuan yang berhubungan dengan karier.

Kedua indikator sikap mendukung inquiry sains kemampuan untuk menyatakan pentingnya mempertimbangkan perbedaan perspektif sains dan argumen, mendukung penggunaan informasi faktual dan ekplanasi, dan menunjukkan kebutuhan untuk proses logis dan ketelitian dalam menarik kesimpulan. Hasil penelitian dapat dilihat pada tabel di bawah ini. 
Nunung Paryati, Fitri Yuliawati

Tabel 4. Hasil penelitian literasi sains dimensi sikap indikator mendukung inquiry sains dan indikator sikap ketertarikan terhadap sains

\begin{tabular}{|c|c|c|c|c|c|c|c|c|c|}
\hline \multirow[b]{2}{*}{ Sample } & \multicolumn{5}{|c|}{ No Soal } & \multirow[b]{2}{*}{$\mathbf{R}$} & \multirow[b]{2}{*}{$\mathbf{N}$} & \multirow[b]{2}{*}{ Skor } & \multirow[b]{2}{*}{ Kriteria } \\
\hline & 13 & 14 & 20 & 26 & 30 & & & & \\
\hline 1 & 1 & 1 & 1 & 1 & $\overline{0}$ & 4 & 5 & 80 & Tinggi \\
\hline 2 & 1 & 1 & 0 & 1 & 1 & 4 & 5 & 80 & Tinggi \\
\hline 3 & 1 & 1 & 1 & 1 & 0 & 4 & 5 & 80 & Tinggi \\
\hline 4 & 1 & 0 & 0 & 1 & 0 & 2 & 5 & 40 & Sangat Rendah \\
\hline 5 & 0 & 0 & 0 & 0 & 1 & 1 & 5 & 20 & Sangat Rendah \\
\hline 6 & 1 & 1 & 1 & 1 & 1 & 5 & 5 & 100 & Sangat Tinggi \\
\hline 7 & 1 & 1 & 0 & 1 & 1 & 4 & 5 & 80 & Tinggi \\
\hline 8 & 1 & 1 & 1 & 1 & 0 & 4 & 5 & 80 & Tinggi \\
\hline 9 & 1 & 1 & 0 & 1 & 1 & 4 & 5 & 80 & Tinggi \\
\hline 10 & 1 & 1 & 0 & 1 & 0 & 3 & 5 & 60 & Sedang \\
\hline 11 & 1 & 0 & 0 & 0 & 0 & 1 & 5 & 20 & Sangat Rendah \\
\hline 12 & 1 & 1 & 1 & 1 & 0 & 4 & 5 & 80 & Tinggi \\
\hline 13 & 1 & 1 & 0 & 1 & 0 & 3 & 5 & 60 & Sedang \\
\hline 14 & 1 & 1 & 1 & 1 & 0 & 4 & 5 & 80 & Tinggi \\
\hline 15 & 0 & 1 & 0 & 1 & 0 & 2 & 5 & 40 & Sangat Rendah \\
\hline 16 & 0 & 1 & 1 & 1 & 1 & 4 & 5 & 80 & Tinggi \\
\hline 17 & 1 & 1 & 1 & 1 & 0 & 4 & 5 & 80 & Tinggi \\
\hline 18 & 1 & 1 & 1 & 1 & 1 & 5 & 5 & 100 & Sangat Tinggi \\
\hline 19 & 1 & 1 & 1 & 1 & 0 & 4 & 5 & 80 & Tinggi \\
\hline 20 & 1 & 1 & 1 & 1 & 1 & 5 & 5 & 100 & Sangat Tinggi \\
\hline 21 & 0 & 1 & 1 & 1 & 0 & 3 & 5 & 60 & Sedang \\
\hline 22 & 1 & 1 & 0 & 1 & 1 & 4 & 5 & 80 & Tinggi \\
\hline 23 & 0 & 1 & 1 & 1 & 1 & 4 & 5 & 80 & Tinggi \\
\hline 24 & 0 & 1 & 1 & 0 & 1 & 3 & 5 & 60 & Sedang \\
\hline 25 & 1 & 1 & 1 & 1 & 0 & 4 & 5 & 80 & Tinggi \\
\hline 26 & 1 & 1 & 1 & 1 & 0 & 4 & 5 & 80 & Tinggi \\
\hline 27 & 0 & 1 & 1 & 0 & 1 & 3 & 5 & 60 & Sedang \\
\hline 28 & 1 & 1 & 1 & 1 & 0 & 4 & 5 & 80 & Tinggi \\
\hline 29 & 0 & 1 & 1 & 0 & 1 & 3 & 5 & 60 & Sedang \\
\hline 30 & 1 & 1 & 1 & 1 & 1 & 5 & 5 & 100 & Sangat Tinggi \\
\hline 31 & 1 & 1 & 0 & 1 & 1 & 4 & 5 & 80 & Tinggi \\
\hline 32 & 1 & 1 & 1 & 1 & 1 & 5 & 5 & 100 & Sangat Tinggi \\
\hline 33 & 1 & 1 & 1 & 1 & 0 & 4 & 5 & 80 & Tinggi \\
\hline 34 & 1 & 1 & 1 & 1 & 0 & 4 & 5 & 80 & Tinggi \\
\hline 35 & 0 & 1 & 0 & 1 & 0 & 2 & 5 & 40 & Sangat Rendah \\
\hline 36 & 0 & 1 & 0 & 1 & 0 & 2 & 5 & 40 & Sangat Rendah \\
\hline Total Benar & 26 & 33 & 23 & 31 & 16 & & & & \\
\hline Persentase & $72,22 \%$ & $91,66 \%$ & $63,88 \%$ & $86,11 \%$ & $44,44 \%$ & & & & \\
\hline
\end{tabular}


Soal nomor 13 tentang $\mathrm{pH}$ air. $\mathrm{pH}$ sendiri berarti derajat keasaman yang digunakan untuk menyatakan tingkat keasaman atau kebasaan yang dimiliki oleh suatu larutan. Soal yang dipertanyakan yakni Adi melakukan pemeriksaan terhadap kualitas air di kolamnya. Dari hasil pengukurannya diperoleh data bahwa $\mathrm{pH}$ air sama dengan 7 . Untuk dapat menyimpulkan apakah kualitas air kolam Adi tersebut tercemar atau tidak, penyelidikan apa yang dapat diajukan oleh Adi.

Pilihan jawaban yang disediakan yakni pertama (a) Ph sama dengan 7 pada kolam dapat dijadikan budidaya ikan yang baik karena $\mathrm{pH}$ nya netral. Kedua (b) pH sama dengan 7 pada kolam dapat dijadikan budidaya ikan yang buruk karena pHnya netral. Ketiga (c) pH sama dengan 7 pada kolam dapat dijadikan budidaya ikan yang baik karena $\mathrm{pH}$ nya asam. Keempat (d) $\mathrm{pH}$ sama dengan 7 pada kolam dapat dijadikan budidaya ikan yang buruk karena pHnya asam. Pilihan jawaban yang benar yakni pilihan yang pertama (a) yang menyatakan bahwa $\mathrm{pH} 7$ sebagai $\mathrm{pH}$ yang netral. Jumlah peserta didik yang dapat menjawab benar yakni sebanyak $72,22 \%$.

Soal nomor 14 tentang ekologi atau ilmu yang mempelajari tentang lingkungan. Sebelum diberi pertanyaan disediakan paragraf yang isinya sebagai berikut ini: pada perkembangannya manusia akan semakin banyak. Pertambahan penduduk, mengakibatkan perlunya perluasan lahan. Salah satunya membuka lahan baru, digunakan persawahan atau rumah. Perkembangan di kota juga sangat berpengaruh. Semakin banyaknya industri-industri besar menyebabkan lahanlahan kosong daerah resapan air hilang. Pengaruh inilah, yang membuat danau dan sungai kering.
Berdasarkan paragraf cerita tersebut, peserta didik diberi pertanyaan yakni tindakan apa yang paling efektif yang dapat dilakukan dalam mengatasi permasalahan tersebut. Pilihan jawaban yang disediakan yakni pertama (a) melestarikam hutan dari penebangan liar. Kedua (b), mengubah daerah resapan air menjadi perumahan, sawah dan industri. Ketiga (c), membiarkan lahan kosong di sekitar rumah tidak ditanami dengan tumbuhan dan terakhir membiarkan sungai dan danau tercemar oleh sampah dan limbah industri. Pilihan jawaban yang benar yakni pilihan pertama (a) melestarikan hutan dari penebangan liar. Jumlah peserta didik yang menjawab benar sebanyak 91, 66\%.

Soal nomor 20 tentang ciri khas penyelidikan ilmiah. Peserta didik diminta memilih jawaban yang benar tentang ciri khas penyelidikan ilmiah berdasarkan wacana dalam paragraf sebagai berikut: Salah satu sumberdaya air yang masih belum dimanfaatkan secara maksimal yakni air hujan. Dilihat dari potensinya, Indonesia merupakan negara yang curah hujannya cukup tinggi. Air hujan merupakan air yang relatif bersih dan kualitasnya cenderung lebih baik dibandingkan air permukaan. Sebagai upaya untuk mencukupi kebutuhan air dan mensubtitusi penggunaan air tanah yang berlebihan maka perlu diupayakan teknologi sistem pemanfaatan air hujan (SPAH).

Kabupaten Pandeglang termasuk daerah yang memiliki curah hujan yang cukup yakni antara 2000-4000 $\mathrm{mm}$ per tahun dengan rata-rata curah hujan sekitar $3.814 \mathrm{~mm}$ dan mempunyai 177 hari hujan rata-rata per tahun serta memiliki tekanan udara rata-rata 1.010 milibar. Namun ironisnya justru permasalahan banjir dan kekeringan menjadi hal yang sering terjadi di Kabupaten Pandeglang. Untuk 
itu manajeman pengelolaan sumberdaya air dengan memanfaatkan air hujan sangatlah tepat diterapkan di Kabupaten ini. Lebih lanjut dikatakan Ridwan bahwa dalam kerangka pembangunan nasional, air merupakan salah satu pioritas utama, bahkan dalam tataran global sekalipun. "Bahwa kemudian jadi masalah itu karena kita tidak bijak dalam mengelola air. Hal tersebut disebabkan oleh kekurangmampuan memahami perilaku air dan kondisinya serta yang lebih berat masalahnya adalah kekurangpedulian kita terhadap air," jelasnya. (Badan Pengkajian dan Penerapan Teknologi, Mei 2012)

Pilihan jawaban yang disediakan pada soal nomor 20 yakni pertama (a) SPAH merupakan teknologi yang digunakan dengan memanfaatkan air hujan yang kemudian diolah sehingga dapat menjadi air minum. Kedua (b), SPAH merupakan teknologi yang digunakan dengan memanfaatkan air bawah tanah yang kemudian diolah menjadi air bersih. Ketiga (c), SPAH merupakan teknologi yang digunakan perusahaan air minum untuk membuat air minum kemasan. Terakhir atau keempat (d) yakni SPAH merupakan teknologi yang digunakan PLTA untuk memutarkan turbin sehingga bisa menghasilkan listrik. Pilihan jawaban yang benar yakni pilihan kedua (b). Jumlah peserta didik yang dapat menjawab benar yakni sebanyak $63,88 \%$.

Soal nomor 26 ekosistem pantai, peserta didik diminta memilih jawaban yang benar tentang hal yang dilakukan untuk mengatasi abrasi dipantai. Pilihan jawaban yang disediakan yakni pertama (a) melarang pengunjung mandi di pantai. Kedua ((b) membangun rumah di sekitar pantai. Ketiga (c) menyediakan tong sampah di pantai dan terakhir (d) menanami tanaman bakau di pantai. Pilihan jawaban yang benar yakni pilihan yang terakhir (d). Jumlah peserta didik yang dapat menjawab benar yakni sebanyak $86,11 \%$.

Soal nomor 30 tentang merokok, peserta didik diminta memilih jawaban yang benar tentang hal yang harus dilakukan untuk menyadarkan orang akan bahaya merokok. Sebelumnya disediakan paragraf sebagai berikut: merokok pada dasarnya menyebabkan gangguan kesehatan. Rokok dapat membuat pecandunya menderita penyakit seperti gangguan pernapasan, batuk kering, hingga nyeri pada paru-paru. Pilihan jawaban yang disediakan yakni membuat kawasan dilarang merokok, menggunakan masker, mengingatkan mereka dan terakhir menjauhi mereka. Pilihan jawaban yang benar yakni pilihan ketiga (c) mengingatkan mereka. Jumlah peserta didik yang dapat menjawab benar yakni sebanyak 44, $44 \%$.

\section{KESIMPULAN}

Dari hasil penelitian dapat disimpulkan bahwa kemampuan literasi sains peserta didik di kelas VC SD Muhammadiyah Condongcatur Sleman Yogyakarta tahun ajaran 2016-2017 terbagi menjadi 5 kriteria. Kriteria sangat tinggi terdapat 7 peserta didik atau sebanyak 19,44\%, kriteria tinggi terdapat 5 peserta didik atau sebanyak $13,88 \%$, kriteria sedang terdapat 16 peserta didik atau sebanyak $44,44 \%$, kriteria rendah terdapat 3 peserta didik atau sebanyak $8,33 \%$ dan kriteria sangat rendah terdapat 5 peserta didik atau sebanyak $13,88 \%$.

\section{DAFTAR PUSTAKA}

Anonim (Artikel). Taman Pintar science center sebagai sarana litersi sains masyarakat, di akses di http:/inovasi.lan.go.id/index. 
Analisis Kemampuan Literasi Sains di Kelas VC SD Muhammadiyah Condongcatur Sleman YK

php? $\mathrm{f}=$ download/getFile\&id=293 pada

tanggal 16 Maret 2017 pukul 17.15 WIB

Hayat, Bahrul dan Yusuf, Suhendra.

Benchmark Internasional Mutu

Pendidikan. Jakarta: Bumi Aksara, 2010.

Sutisnawati, Asri. 2015. "Membangun Imajinasi dan Kreativitas Anak Melalui Literasi Sains" (Penerapan Literasi Sains di Sekolah Dasar). Vol 2, Prosiding Seminar Pendidikan Dasar. Di akses di http://eprints.uad. ac.id/2845/1/\%5BBURN $\% 5$ D $\% 20$ Prosiding\%20Pendas \%202015\%20 Vol\%202.pdf pada tanggal 17 April 2017 pukul 12.00

Toharudin, Uus et al. Membangun Literasi Sains Peserta Didik. (Ed) Nuryani Y. Rustaman. Bandung: Humaniora, 2011. 
